\title{
Body size and mating success in Pyrrhocoris apterus (Heteroptera)
}

\author{
ALOIS HONĚKK \\ Research Institute of Plant Production, Drnovská 507, CZ-161 06 Praha 6 - Ruzyně 507, Czech Republic; e-mail: honek@vurv.cz
}

Key words. Pyrrhocoris apterus, males, females, sex ratio, copulation, assortative mating, mating duration, population density, group size

\begin{abstract}
The effects of body size on mating success and duration of copulation were investigated in Pyrrhocoris apterus. Under laboratory conditions relative mating success of small and large males was investigated in groups of 2 males (majority sex) : 1 female (minority sex). Large males were recorded significantly more often in copulation than small males when the female was large but not when the female was small. This was also the case when the group size was 24 males : 12 females or population density decreased by increasing the area of the experimental arena. In groups of 2 females : 1 male, large females were recorded in copulation significantly more often than small females when the male was large but not when the male was small. Proportion of individuals of the minority sex that copulated was similar for males and females, regardless of body size. The average duration of copulation was similar for small and large males, but shorter for small than large females. The difference in the duration of copulation of small and large females was greater when it was with small rather than large males. The prolonged guarding of large females by small males may be explained by a trade-off between increasing the probability of inseminating an uneasily accessible high quality partner and copulating with more females.
\end{abstract}

\section{INTRODUCTION}

Mating performance is an important component of individual fitness and, in many insect species, body size is a factor that affects mating success. The importance of body size in mating behaviour vary with sex, mating system and environmental conditions (Honěk, in litt.). Large males are usually more successful in obtaining mates (Markow \& Sawka, 1992) and this is manifested in species with different mating systems, including those where males select females without apparent male-male competition (Brown, 1990a) as well as those in which large males gain females by providing greater nuptial gifts or after competitng with other males (Shimizu \& Fujiyama, 1986). Cases where body size has little effect on male competitiveness are relatively rare (Tammaru et al., 1996). For females large body size may increase their attractiveness to males and enable them to reject males. Males often prefer large females (Lawrence, 1986; Svensson et al., 1989). Females may prefer copulating with large males (Goulson et al., 1993) but are more likely to be indifferent to the size of their mate than males (Droney, 1992).

The duration of copulation (Brown, 1990b) and postcopulatory guarding of a female (Crespi, 1986, 1988) are usually positively correlated with male body size but these characteristics are influenced also by other factors (Brown \& Stanford, 1992). Large female size may increase the length of male mate guarding (Dodson \& Marshall, 1984). The postcopulatory mate guarding may exceed many times the minimum time needed for insemination (Harris \& Todd, 1980; Sillen-Tullberg, 1981; Carroll, 1991).

To reveal the effect of body size on mating success it is necessary to study species with simple copulation behaviour where the effect of partner size is not confounded by a complicated mating ritual. A convenient subject is $P y r-$ rhocoris apterus L. (Heteroptera, Pyrrhocoridae) which has an overt mode of life and for which detailed information on its biology is already available (Socha, 1993). In central Europe this species can be found at the bases of linden (Tilia spp.) trees, whose seed they eat. It has usually one generation per year (Honěk \& Šrámková, 1976). Diapausing adults overwinter, mating and egg laying start in early spring and continue until the death of animals several weeks later. $P$. apterus manifest a subsocial behaviour (Melber \& Schmidt, 1977). With first spells of warm and sunny weather (March-April) thermoregulation basking in sunny spots results in massive assemblages of thousands of overwintered individuals. These aggregations facilitate mating. Copulation occurs at intervals throughout the reproductive period until the death of the animals. Under laboratory conditions, and apparently also in the field, each adult copulates several times. The number and frequency of copulations under natural conditions is not known. The neuroendocrine regulation of reproduction (Hodkova \& Hodek, 1989; Hodkova \& Socha, 1995; Hodkova, 1999) and mating (Žd'árek, 1968, 1970, 1971; Hodkova, 1994) are well studied and are both controlled by photoperiod and temperature. There is no special courtship behaviour, male fighting or territoriality. Sexually active males are attracted by female pheromone (composition not known), locate females visually from a short distance and mount them shortly after making contact (Socha, 1993). Sexual activity is highest at the start of the season and then declines. Body length of adults varies between $6.5-12.5 \mathrm{~mm}$, and the average values vary between localities and years (Honěk, 1981). As in other Pyrrhocoris species (Sakashita et al., 1997), environmental factors affecting adult body size are egg size (Honěk, 1987, 1992), food supply in the last larval 
TABLE 1. The effect of the difference between the average male and the female size ( $=$ female length - [large male length + small male length]/2) on the proportion of copulations with large males and percentage of cases where no copulations were recorded.

\begin{tabular}{|c|c|c|c|c|c|c|c|}
\hline \multirow{2}{*}{$\begin{array}{l}\text { Difference in } \\
\text { size between } 9 \\
\text { and } \delta\end{array}$} & \multirow[t]{2}{*}{ Replicates } & \multirow{2}{*}{$\begin{array}{c}\text { No } \\
\text { copulation }\end{array}$} & \multicolumn{3}{|c|}{ Male copulating } & \multirow{2}{*}{$\begin{array}{c}\text { Percentage of copulations } \\
\text { with large males }\end{array}$} & \multirow{2}{*}{$\begin{array}{l}\text { Percentage of cases } \\
\text { with no copulation }\end{array}$} \\
\hline & & & Small & Large & & & \\
\hline $\mathrm{mm}$ & $\mathrm{n}$ & $\mathrm{n}$ & $\mathrm{n}$ & $\mathrm{n}$ & chi-square & $\mathrm{x} \pm \mathrm{SEM}$ & $\mathrm{x} \pm \mathrm{SEM}$ \\
\hline 0.75 & 9 & 12 & 35 & 36 & 0.01 & $49.0 \pm 4.8 b$ & $15.1 \pm 3.5 b$ \\
\hline $1.0-1.5$ & 7 & 8 & 26 & 40 & 2.97 & $63.1 \pm 4.6 \mathrm{c}$ & $11.4 \pm 5.1 \mathrm{bc}$ \\
\hline$\geq 1.75$ & 9 & 9 & 20 & 70 & $27.79 \mathrm{a}$ & $77.7 \pm 2.7 \mathrm{~d}$ & $8.2 \pm 2.7 \mathrm{c}$ \\
\hline
\end{tabular}

a Rows: difference in proportion of small and large males that copulated significant at $\mathrm{p}<0.05$ (chi-square test).

b-d Columns: differences between figures with the same letter not significant at $\mathrm{p}<0.05$ (t-test).

instar and developmental temperature (Honěk, 1987). Adult body size influences a number of fitness characteristics, particularly fecundity (Honěk, 1992).

In this laboratory study the effect of body size on (1) mating success and (2) duration of copulation were studied. The variation in the duration of copulation is discussed in context with a postulated trade-off between the number of females inseminated and mate guarding.

\section{MATERIAL AND METHODS}

Experimental insects. From 1988-1997 the laboratory experiments were done using post-diapause individuals collected at three localities in western part of the Czech Republic $\left(49^{\circ} 54^{\prime}-50^{\circ} 24^{\prime} \mathrm{N}\right.$ and $\left.14^{\circ} 00^{\prime}-14^{\circ} 50^{\prime} \mathrm{E}\right)$ in late March - early April. Experimental animals were always collected before the end of hibernation, when they were still hidden in the litter at the bases of lime trees. The bugs were transported to the laboratory in sterile plastic bottles, sexed and sorted according to size (body length measured from the tip of the head to the hind margin of the last abdominal tergite). Groups of 30-60 individuals were then kept (each sex separately) in $5 \mathrm{~cm}$ deep glass vials of $25 \mathrm{~cm}$ diameter covered with nylon fabric. The surface area was increased by inserting a sheet of folded filter paper The bugs were supplied with linden seed (Tilia cordata Miller) and water. The bugs were kept and experiments done at $23-25^{\circ} \mathrm{C}$ and a natural photoperiod (April-May, photophase 13.7-16.0 h), away from direct sunlight. Under these conditions all individuals became sexually active within 2 weeks.

Layout of experiments. The experiments on mating and postcopulatory mate guarding were done in round plexite or glass dishes of 6,15 and $25 \mathrm{~cm}$ diameter ("arenas"). The dishes were open and their vertical walls smeared with butter to prevent the escape of the insects. Males and females were introduced into an experimental arena in the ratio of 1 (minority sex) : 2 (majority sex). In the experiments on mating, the majority sex was introduced first and the minority sex added ca $30 \mathrm{~s}$. later. The outcome (i.e. whether the minority sex mated with the larger or the smaller partner) were recorded 5, 10, 30 and 60 mins after introducing the minority sex into the arena. Neither food nor water were present during the experiment. In all experiments individuals kept for $\geq 3$ days without access to the opposite sex were used. To avoid repeated measures, males and females were not re-used in the same experiments.

Importance of differences in body length. The effect of the size difference between the sexes on mating was investigated in three-individual groups in arenas of $6 \mathrm{~cm}$ diameter. Pairs consisting of a small $(\leq 9.00 \mathrm{~mm})$ and a large $(\geq 10.00 \mathrm{~mm})$ male were placed with a female whose size was greater than the average size of the males (the sum of body lengths of the larger and the smaller male divided by two). The difference between average male and female size was $\leq 0.75 \mathrm{~mm}, 1.0-1.5 \mathrm{~mm}$, or $\geq 1.75 \mathrm{~mm}$. Other procedures were similar to above.

Size of mates of majority and minority sex. The bugs of both sexes were divided into two groups, "small" and "large", according to their size. The limits for classifying an animal as "small" or "large" varied since average body size varied between local populations from which the experimental animals were taken. The upper limit of body length in "small" males was 9.00-9.25 mm, in "small" females it was $9.50-9.75 \mathrm{~mm}$. Lower limit of body length for "large" males was 10.00-10.25, for "large" females 11.00-11.25 mm. The minimum differences between "small" and "large" individuals of the same sex used in a particular trial were always $\geq 1 \mathrm{~mm}$. Males and females were introduced into experimental arenas in groups of 3 individuals consisting of 1 male and 2 females or 1 female and 2 males, or groups of 36 individuals consisting of 12 males and 24 females. Using different group and arena sizes resulted in the area available to an individual (population density) being between ca. 6 and $164 \mathrm{~cm}^{2}$.

Duration of copulation. The length of copulation was measured on pairs that mated after bringing together a group of small and large males and females. Groups of 15-25 individuals of each sex were introduced for $1 \mathrm{~h}$ into a large arena (diameter 25 $\mathrm{cm})$ where they began to copulate. These individuals were free to mate with either a small or a large partner. Copulating pairs were then transferred using forceps and each placed in an arena of $6 \mathrm{~cm}$ diameter and provided with linden seed and water. The duration of copulation of each pair was recorded at $3 \mathrm{~h}$ intervals.

Data processing. Simultaneously established series of experimental groups in which the proportion of large and small partners were recorded are called replicates. Replicates consisted of 8-20 three-individual groups ( 2 males vs. 1 female, 2 females vs. 1 male) or 1-4 thirty six-individual groups (24 males vs. 12 females). Each experiment (a row in Tables 1-3) consisted of 7-24 replicates. The proportions of small and large individuals that copulated in a particular experiment were calculated as arithmetic means (x) \pm standard errors of mean (SEM) of the proportions established in replicates (all copulations in a given replicate $=100 \%$ ). The significance of the within experiment difference between small and large animals was evaluated by chi-square test using cumulative numbers of small and large individuals that copulated in all replicates assuming equal probability of copulation as the null hypothesis. Proportions of groups where copulation with the large partner or no copulation was recorded were calculated as arithmetic means $\mathrm{x} \pm \mathrm{SEM}$ of proportions (total number of groups in a replicate is equivalent to $100 \%$ ). The differences in the mean proportions of large individuals in copulation and groups where there was no copula were tested by t-test. The differences in the length of copulation 


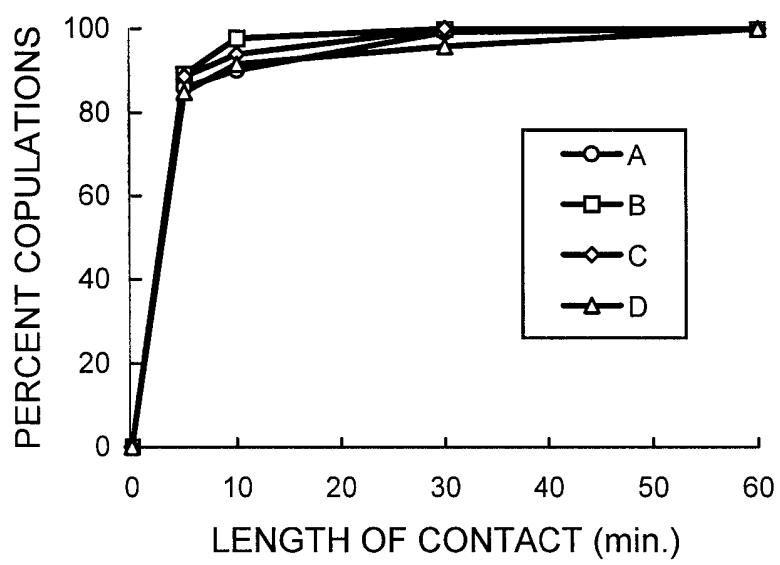

Fig. 1. Cumulative percentage of copulation recorded at 5, 10, 30 and $60 \mathrm{~min}$. after bringing the sexes together. A - small male with small and large females; B - large male with small and large females; $\mathrm{C}$ - small and and large male with small female; $\mathrm{D}$ - small and large male with large female. Data for 679 groups of 3 individuals.

were tested using Kolmogorov-Smirnov non-parametric test (Reisenauer, 1965).

\section{RESULTS}

\section{Copulation behaviour}

The males quickly located females, usually encountering them during the chaotic crawling typical of the start of an experiment. No courtship was observed. The typical pre-copulatory sequence involved three postures. (1) The male stood parallel to the female, side by side or gripped her neck. (2) The male then extended and rotated his aedeagus and attached it to the genital opening of the female. During these precopulation phases other males frequently tried to detach the copulating male from the female and take his position, rarely with success. (3) The male then descended from the female and rotated its position by 180 degrees so that both copulating animals faced in the opposite direction, joined by the extended aedeagus. This position was usually established 3-5 minutes after onset of copulation and lasted for its rest. During this period copulating individuals moved and fed freely and other males made little attempt to displace the copulating male.

Phase (1) usually lasted few seconds. Behaviour indicating male selection or female refusal during this short period could only be established using slow motion records not available in this study. Copulations (positions 2 and 3) were usually established soon after the males and females were brought together. In triads (Fig. 1) $87.1 \pm$ $1.8 \%$ of the copulations were in process when first checked, 5 minutes after the start of the experiment. Copulations occurred as quickly as in groups of 36 individuals.

\section{Importance of differences in body length}

The first experiment investigated the significance of the magnitude of the difference in size between male and female on the incidence of mating by large males (Table 1). The incidence increased as relative female size increased. The proportions of large and small males that copulated when the relative female size was only $\leq 0.75$ $\mathrm{mm}$ greater than the average male size were similar (49.0\% were with large males). The incidence of mating with large males increased when the relative female size was $1.0-1.5 \mathrm{~mm}$ larger than the average male size (63.1 $\%$ were with large males) and was maximum when the relative female size was $>1.75 \mathrm{~mm}$ larger than the average male size $(77.7 \%$ were with large males, $\mathrm{p}<$ $0.01)$. Associated with this was a decrease in the proportion of females unmated. The percentage of females unmated no copulation significantly decreased (Table 1) as the relative size of the females increased. Thus only $8.2 \%$ of large females (difference $\geq 1.75 \mathrm{~mm}$ ) were unmated compared to $15.1 \%$ of small females (difference $\leq 0.75 \mathrm{~mm}$ ).

\section{Incidence of mating with males when they outnumbered females}

These experiments were done with both small and large individuals. The differences in the incidence of mating with small or large individuals were significant only in certain situations. As in the above experiments, more large males were recorded copulating than small males when with large females and this difference was smaller

TABLE 2. Proportion of males copulating with large and small female, when males were the majority sex (ratio 1 female : 2 males). Copulations recorded $60 \mathrm{~min}$. after the start of the experiment. Group size (no. of individuals per experimental vial) and population density (surface area available per individual) were varied.

\begin{tabular}{|c|c|c|c|c|c|c|c|c|c|}
\hline \multirow{3}{*}{$\begin{array}{l}\text { Group size } \\
\text { individuals }\end{array}$} & \multirow{3}{*}{$\begin{array}{c}\text { Area per } \\
\text { individual } \\
\mathrm{cm}^{2}\end{array}$} & \multirow{3}{*}{$\begin{array}{c}\text { Female } \\
\text { size }\end{array}$} & \multirow{3}{*}{$\begin{array}{c}\text { Replicates } \\
\text { n }\end{array}$} & \multirow{3}{*}{$\begin{array}{c}\text { No } \\
\text { copulation } \\
\\
n\end{array}$} & \multicolumn{3}{|c|}{ Males in copula with female } & \multirow{3}{*}{$\begin{array}{l}\text { Percentage of } \\
\text { copulations with } \\
\text { large males } \\
\mathrm{x} \pm \text { SEM }\end{array}$} & \multirow{3}{*}{$\begin{array}{c}\text { Percentage of } \\
\text { cases with no } \\
\text { copulation } \\
\mathrm{x} \pm \text { SEM }\end{array}$} \\
\hline & & & & & Small & Large & & & \\
\hline & & & & & $\mathrm{n}$ & $\mathrm{n}$ & chi-square & & \\
\hline 3 & 6.5 & Small & 11 & 60 & 58 & 56 & 0.04 & $46.5 \pm 3.7 b$ & $32.0 \pm 6.1 \mathrm{~b}$ \\
\hline 3 & 6.5 & Large & 10 & 47 & 41 & 78 & $11.50 \mathrm{a}$ & $66.5 \pm 4.8 \mathrm{~d}$ & $25.7 \pm 7.0 \mathrm{bc}$ \\
\hline 36 & 5.6 & Small & 10 & 17 & 60 & 43 & 2.81 & $40.9 \pm 2.6 b$ & $14.2 \pm 3.7 \mathrm{~d}$ \\
\hline 36 & 5.6 & Large & 14 & 10 & 66 & 92 & $4.29 \mathrm{a}$ & $58.2 \pm 3.3 \mathrm{c}$ & $6.0 \pm 1.6 \mathrm{e}$ \\
\hline 3 & 163.6 & Small & 8 & 17 & 39 & 29 & 1.47 & $40.8 \pm 8.0 \mathrm{~b}$ & $21.3 \pm 4.5 \mathrm{~d}$ \\
\hline 3 & 163.6 & Large & 8 & 14 & 24 & 46 & $3.85 \mathrm{a}$ & $60.0 \pm 7.1 \mathrm{~cd}$ & $14.9 \pm 3.9 \mathrm{~cd}$ \\
\hline
\end{tabular}

a Rows: difference in proportion of small and large males that copulated significant at $p<0.05$ (chi-square test).

b-e Columns: differences between figures with the same letter not significant at $\mathrm{p}<0.05$ (t- test). 
TABLE 3. Proportion of females recorded copulating with large and small males, when females were the majority sex (ratio 1 male : 2 females). Copulations recorded $60 \mathrm{~min}$. after the start of the experiment.

\begin{tabular}{|c|c|c|c|c|c|c|c|c|c|}
\hline \multirow[t]{2}{*}{ Group size } & \multirow{2}{*}{$\begin{array}{l}\text { Area per } \\
\text { individual }\end{array}$} & \multirow[t]{3}{*}{ Male size } & \multirow[t]{2}{*}{ Replicates } & \multirow{2}{*}{$\begin{array}{c}\text { No } \\
\text { copulation }\end{array}$} & \multicolumn{3}{|c|}{ Size of female in copula } & \multirow{3}{*}{$\begin{array}{l}\text { Percentage of } \\
\text { copulations with } \\
\text { large females }\end{array}$} & \multirow{2}{*}{$\begin{array}{c}\text { Percentage of } \\
\text { cases with no } \\
\text { copulation }\end{array}$} \\
\hline & & & & & Small & Large & & & \\
\hline individuals & $\mathrm{cm}^{2}$ & & $\mathrm{n}$ & $\mathrm{n}$ & $\mathrm{n}$ & $\mathrm{n}$ & chi-square & & $\mathrm{x} \pm \mathrm{SEM}$ \\
\hline 3 & 6.5 & Small & 10 & 49 & 55 & 66 & 1.00 & $53.8 \pm 1.5 \mathrm{a}$ & $26.9 \pm 0.9 \mathrm{a}$ \\
\hline 3 & 6.5 & Large & 10 & 41 & 42 & 86 & $15.13 \mathrm{a}$ & $68.6 \pm 0.8 b$ & $22.7 \pm 0.9 b$ \\
\hline
\end{tabular}

a Rows: difference in proportion of small and large females that copulated significant at $\mathrm{p}<0.05$ (chi-square test).

b-e Columns: differences between figures with the same letter not significant at $p<0.05$ (t- test).

when they were with small females (Table 2). The higher incidence of mating with large females was similar in groups of 3 or 36 individuals with $6.5 \mathrm{~cm}^{2}$ available per individual or when the area was $163.6 \mathrm{~cm}^{2}$ per individual. In each of these experiments the difference in the incidence of mating of small and large males with large females was statistically significant $(\mathrm{p}<0.05)$, but not the difference in frequency of copulations with small females. The proportion of groups where no copulation was observed within $1 \mathrm{~h}$ was greater for those with small rather than large females. This difference was similar regardless of group size and area available per individual. The proportion of non-mated females was the least when group size was 36 . Increasing the number of potential mates may thus increase the probability of copulation.

\section{Incidence of mating with females when they outnumbered males}

When females were the majority sex mating was only recorded in 3 individual groups with area of $6.5 \mathrm{~cm}^{2}$ available per individual. More large females were recorded in copulation than small females (Table 3 ). With small males the difference was not significant but with large males more large females were recorded in copulation than small females. Proportion of groups where no copulation was recorded was significantly greater when females were put with small rather than large males.

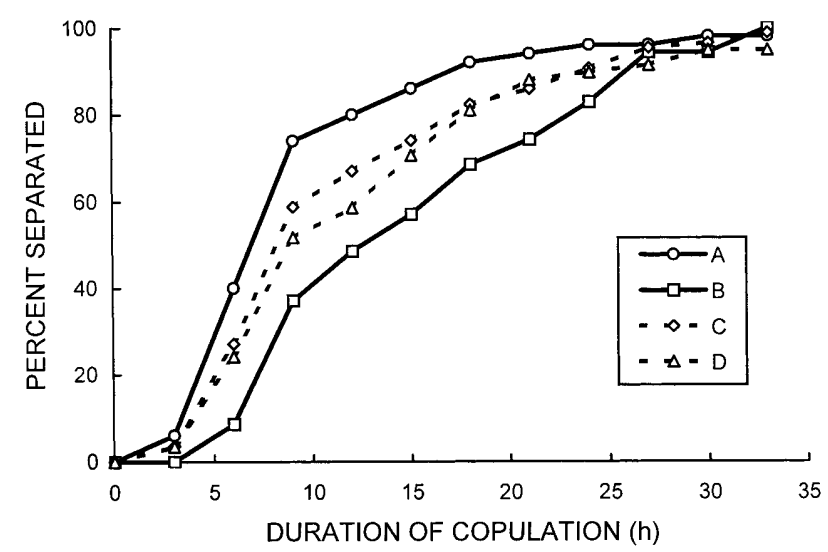

Fig. 2. The cumulative percentage of copulations that were terminated (percent copulating pairs that separated) in time from the start of copulation (duration of copulation). A - small male with small female; $\mathrm{B}$ - small male with large female; $\mathrm{C}$ - large male with small female; D - large male with large female. Data for 401 pairs.

\section{Incidence of mating of the minority sex}

The results of experiments using groups of 3 individuals in which males and females were offered a surplus of the opposite sex are given in Table 4. The incidence of copulation was little affected by body size. The average percentage of copulations recorded was slightly greater for males than females for large than small individuals. As these differences were not significant the incidence of mating was little affected by variation in the appetitive behaviour of the minority sex.

\section{Duration of copulation}

Further experiments investigated the effect of body size of the partners on the duration of copulation. Regardless of body size of the partners copulation was usually prolonged. Only $3.3 \%$ were terminated within $3 \mathrm{~h}$ and $22.0 \%$ within $6 \mathrm{~h}$. The modal length of copulation was $9 \mathrm{~h}$, the average length was $13.1 \pm 0.4 \mathrm{~h}$. The distribution of times spent in copula was left skewed and only $2 \%$ of copulations was longer than $33 \mathrm{~h}$. The duration of copulations varied little with male size (Kolmogorov-Smirnov test: sample size $\mathrm{N}_{1}=94, \mathrm{~N}_{2}=85$; maximum difference $\mathrm{D}_{\max }=$ $9 \%$; critical difference $\mathrm{D}_{\mathrm{P}=0.05}=19.1 \%$, N.S.), but was significantly longer for large than for small females (Kolmogorov-Smirnov test: $\mathrm{N}_{1}=93, \mathrm{~N}_{2}=86 ; \mathrm{D}_{\max }=$ $\left.34 \%, \mathrm{D}_{\mathrm{P}=0.01}=22.7 \%, \mathrm{p}<0.01\right)$. The differences in duration of copulation of large and small females were particularly exaggerated by the copulations with small males (Kolmogorov-Smirnov test: $\mathrm{N}_{1}=50, \mathrm{~N}_{2}=35 ; \mathrm{D}_{\max }=37 \%$; $\left.\mathrm{D}_{\mathrm{P}=0.01}=19.5 \%, \mathrm{p}<0.01\right)($ Fig. 2).

\section{DISCUSSION}

The effect of body size on mating success was easy to establish in $P$. apterus due to its simple mating system. Prior to copulation there was no male-male contests or

TABLE 4. Proportion of copulations in small and large males and females when they were the minority sex (the opposite sex was in surplus).

\begin{tabular}{|c|c|c|c|c|c|}
\hline & $\begin{array}{l}\text { Repli- } \\
\text { cates }\end{array}$ & $\begin{array}{c}\text { No } \\
\text { copulation }\end{array}$ & In copula & $\begin{array}{c}\text { Percentage } \\
\text { in copula }\end{array}$ \\
\hline & & $\mathrm{n}$ & $\mathrm{n}$ & $\mathrm{n}$ & $\mathrm{x} \pm \mathrm{SEM}$ \\
\hline \multirow{2}{*}{ Male } & Small & 10 & 44 & 121 & $73.1 \pm 0.9 \mathrm{a}$ \\
\hline & Large & 10 & 41 & 128 & $77.3 \pm 0.9 b$ \\
\hline \multirow{2}{*}{ Female } & Small & 24 & 124 & 236 & $71.3 \pm 1.1 \mathrm{a}$ \\
\hline & Large & 21 & 114 & 229 & $73.4 \pm 1.3 a$ \\
\hline
\end{tabular}

a-b Columns: differences between figures with the same letter not significant at $\mathrm{p}<0.05$ (t- test). 
precopulatory behaviour. Mating depended on male sexual drive and the refusal or the willingness of the female.

The experiments revealed the tendency of both sexes to copulate with mates of a particular size. The males copulated mainly with large females. In the presence of large females large males were recorded in copulation more frequently than small males. In presence of small females the proportion of large and small males recorded in copulation was similar. These observation provided no information on how a partner is selected and the cue for estimating size. The role of female activity was not established. The females appeared either generally receptive to male attempts to mate or refused to copulate. Although proportionally more large males were recorded copulating this was clearly not the consequence of male-male combats. Large males were more sexually active and started copulating earlier. It was not possible to establish the reason for this. Both large and small males resisted the attempts of other males to displace them when in copula. The behavioural factors involved in the assortative mating reported here remain to be studied.

The high incidence of large individuals observed in copulation is consistent with theoretical expectations supported by numerous observations (Crespi, 1989; Honěk, in litt.). A preference for a large mate is expected as body size is positively correlated with several fitness characteristics including fecundity and sperm or ejaculate production. Thus mating with a large partner is advantageous. More interesting were the differences in the length of the copulation associated with the body size of the partners, particularly the prolonged duration of small male vs. large female copulation. Similar variation in duration of the copulation is observed in other species and several explanations offered. The differences may be due to morphological constraints on copulation success in individuals of different size. Thus small males may have difficulty inseminating females (Horton et al., 2001). The variation is explained by a concealed behavioural resistance of females to copulation with small males that provide less ejaculate than large males (Field et al., 1999). In $P$. apterus the duration of copulation includes postcopulatory mate guarding (Honěk \& Šíchová, unpubl.). It is likely the male controls the duration of copulation (cf. Harris \& Todd, 1980; Sillen-Tullberg, 1981; Carroll, 1991) and decides when to release a female, after evaluating her size. There is likely a trade-off between duration of mate guarding, which increases the probability of inseminating the guarded female, and the probability of inseminating other females. A decrease in the duration of copulation with small females and increase in that with large females is predicted. The existence of such a difference was well demonstrated for small males, which remained in copula with large females longer than with small females. This may limit the ability of small males to copulate with large females.

ACKNOWLEDGEMENTS. I thank an anonymous reviewer and Professor A.F.G. Dixon for important comments which greatly increased the value and presentation of the paper. The work was partly supported by the Research Programme M 01-01-03 of the Ministry of Agriculture of the Czech Republic.

\section{REFERENCES}

BRowN W.D. 1990a: Constraints on size-assortative mating in the blister beetle Tegrodera aloga (Coleoptera: Meloidae). Ethology 86: 146-160.

BRown W.D. 1990b: Size-assortative mating in the blister beetle Lytta magister (Coleoptera: Meloidae) is due to male and female preference for larger mates. Anim. Behav. 40: 901-909.

Brown W.D. \& StANFord R. 1992: Male mating tactics in a blister beetle (Coleoptera: Meloidae) vary with female quality. Can. J. Zool. 70: 1652-1655.

CARROLL S.P. 1991: The adaptive significance of mate guarding in the soapberry bug, Jadera haematoloma (Hemiptera: Rhopalidae). J. Insect Behav. 4: 509-530.

CRESPI B.J. 1986: Size assessment and alternative fighting tactics in Elaphrothrips tuberculatus (Insecta: Thysanoptera). Anim. Behav. 34: 1324-1335.

CRESPI B.J. 1988: Alternative male mating tactics in a thrips: effects of sex ratio variation and body size. Am. Midl. Nat. 119: 83-92.

CRESPI B.J. 1989: Causes of assortative mating in arthropods. Anim. Behav. 38: 980-1000.

Dodson G. \& Marshall L. 1984: Mating patterns in an ambush bug Phymata fasciata (Phymatidae). Am. Midl. Nat. 112: $50-57$

DRONEY D.C. 1992: Sexual selection in a lekking Hawaiian Drosophila: the roles of male competition and female choice in male mating success. Anim. Behow. 44:1007-1020.

Field S.A., TAYlor P.W. \& Yuval B. 1999: Sources of variability in copula duration of mediterranean fruit flies. Entomol. Exp. Appl. 92: 271-276.

Goulson D., BrRch M.C. \& Wyatt T.D. 1993: Paternal investment in relation to size in the deathwatch beetle, Xestobium rufovillosum (Coleoptera: Anobiidae), and evidence for female selection for large mates. J. Insect Behav. 6: 539-547.

HARRIS V.E. \& TODD J.W. 1980: Temporal and numerical patterns of reproductive behavior in the southern green stink bug, Nezara viridula (Hemiptera: Pentatomidae). Entomol. Exp. Appl. 27: 105-116.

HodKova M. 1994: Photoperiodic regulation of mating behaviour in the linden bug, Pyrrhocoris apterus, is mediated by a brain inhibitory factor. Experientia 50: 742-744.

Hodkova M. 1999: Regulation of diapause and reproduction in Pyrrhocoris apterus (L.) (Heteroptera) - neuroendocrine outputs (Mini-review). Entomol. Sci. 2: 563-566.

Hodkova M. \& HoDEK I. 1989: Role of feeding, photoperiod and temperature in the regulation of reproduction by the neuroendocrine system in Pyrrhocoris apterus. In: Tonner M., Soldán T. \& Bennettová B. (eds.): Regulation of Insect Reproduction $I V$, Proceedings of a Symposium held in Žinkovy, September 1987. Academia, Praha, pp. 377-384.

Hodkova M. \& SOcHA R. 1995: Effect of temperature on photoperiodic response in a selected "non-diapause" strain of Pyrrhocoris apterus (Heteroptera). Physiol. Entomol. 20: 303-308.

HoNĚK A. 1981: Temperature and wing polymorphism in natural populations of Pyrrhocoris apterus L. (Heteroptera: Pyrrhocoridae). Zool. Jb. Syst. 108: 487-501.

HoNĚK A. 1987: Regulation of body size in a heteropteran bug, Pyrrhocoris apterus. Entomol. Exp. Appl. 44: 257-262. 
HoNĚK A. 1992: Female size, reproduction and progeny size in Pyrrhocoris apterus (Heteroptera: Pyrrhocoridae). Acta Entomol. Bohemoslov. 89: 169-178.

HonĚK A. (in litt.): The effect of body size on mating preferences in insects.

HoNĚK A. \& ŠSRÁMKOVÁ K. 1976: Behavioral regulation of developmental cycle in Pyrrhocoris apterus L. (Heteroptera: Pyrrhocoridae). Oecologia 24: 277-281.

Horton D.R., Lewis T.M. \& Hinojosa T. 2001: Copulation duration and probability of insemination in Anthocoris whitei (Hemiptera: Anthocoridae) as a function of male body size. Can. Entomol. 133: 109-117.

LAWRENCE W.S. 1986: Male choice and competition in Tetraopes tetraophthalmus: effects of local sex ratio variation. Behav. Ecol. Sociobiol. 18: 289-296.

MARKow T.A. \& SAWKa S. 1992: Dynamics of mating success in experimental groups of Drosophila melanogaster (Diptera: Drosophilidae). J. Insect Behav. 5: 375-383.

Melber A. \& Schmid G.H. 1977: Sozialphänomene bei Heteropteren. Zoologica 127: 19-53.

ReISEnaUer R. 1965: Methods of Mathematical Statistics. Státn nakladatelství technické literatury, Praha, 208 pp. [in Czech]

SAKASHITA T., NAKASUI F. \& FuJISAKI K. 1997: Effects of temperature and photoperiod on nymphal development of the stink bug, Pyrrhocoris sibiricus Kuschakewitch (Heteroptera: Pyrrhocoridae). Appl. Entomol. Zool. 32: 153-157.
Shimizu N. \& Fuлryama S. 1986: Aggressive encounters between males in Chrysolina aurichalcea (Coleoptera: Chrysomelidae). J. Ethol. 4: 11-15.

SilleN-Tullberg B. 1981: A male "post-copulatory" strategy in a promiscuous species, Lygaeus equestris (Heteroptera: Lygaeidae). Behav. Ecol. Sociobiol. 9: 283-292.

SOCHA R. 1993: Pyrrhocoris apterus (Heteroptera) - an experimental model species: a review. Eur. J. Entomol. 90: 241-286.

Svensson B.G., Petersson E. \& Forsgren E. 1989: Why do males of the dance fly Empis borealis refuse to mate? The importance of female age and size. J. Insect Behav. 2: 387-395.

Tammaru T., Ruohomäki K. \& Saikkonen K. 1996: Components of male fitness in relation to body size in Epirrita autumnata (Lepidoptera, Geometridae). Ecol. Entomol. 21: 185-192.

Ž́̇́́REK J. 1968: Le comportement d'accouplement a la fin de la diapause imaginale et son contrôle hormonal dans le cas de la punaise Pyrrhocoris apterus L. (Pyrrhocoridae, Heteroptera). Ann. Endocrinol. 29: 703-707.

Ž́̌́RER J. 1970: Mating behaviour in the bug Pyrrhocoris apterus L. (Heteroptera). Behaviour 37: 253-268.

Ž̀̌́́REK J. 1971: Hormonal control of mating behaviour in Pyrrhocoris apterus L. In: Novák V.J.A. \& Sláma K. (eds.): Insect Endocrines. Academia, Praha, pp. 51-61.

Received April 3, 2001; revised October 15, 2002; accepted November 14, 2002 